\title{
Effect of defoliation intensity on regrowth of tallgrass prairie
}

\author{
KENNETH W. TATE, ROBERT L. GILLEN, RONALD L. MITCHELL, AND RUSSELL \\ L. STEVENS.
}

Authors are former senior agriculturalist, Department of Agronomy, Oklahoma State University, Stillwater 74078; associate professor, Department of Agronomy, Oklahoma State University, Stlllwater 74078; pasture specialist and wildlife and fisheries specialist, Samuel Roberts Noble Foundation, Inc., Ardmore, Okla. 73402.

\begin{abstract}
Grazing trials were conducted in north and south-central Oklahoma throughout the growing season of 1989 and 1990 in an attempt to explain live herbage accumulation rate of tallgrass prairie as a function of live residual herbage level. A 1-2 day grazing period on 8 treatment paddocks began 26 May (Trial 1), 7 July (Trial 2), and 18 August (Trial 3) of each year. Two replicate paddocks per trial were subjected to stocking densities of $\mathbf{7 , 6 0 0 \text { , }}$ $15,200,22,700$, and $30,300 \mathrm{~kg}$ animal weight $\mathrm{ha}^{-1}$. Live herbage was measured immediately after grazing to determine live residual herbage level and 2, 4,6, and 8 weeks after grazing to determine live herbage accumulation. Live herbage accumulation rate was determined as the first derivative with respect to day after grazing day of polynomial regression equations fit to live herbage accumulation data. Maximum live herbage accumulation rate decreased as season progressed but the time required to reach maximum live herbage accumulation rate was not dependent upon season. Live residual herbage level was a significant parameter in equations describing live herbage accumulation rate in 6 of 9 trials.
\end{abstract}

Key Words: live herbage accumulation rate, residual herbage level, growth rate

Intensive rotational grazing involves the rapid rotation of 1 herd of livestock through a subdivided pasture at intervals decided upon by a grazing manager (Howell 1978, Savory 1978). Timing herd movement to allow sufficient time for major forage species to regrow following grazing is critical to the success of rotational grazing (Booysen and Tainton 1978, Howell 1978, Savory 1978). Knowledge of the parameters affecting plant regrowth thus is important in managing rotational grazing systems.

Herbage production changes throughout the growing season (Anslow and Green 1967, Williams 1980). Maximum rate of regrowth after clipping decreases as the growing season progresses, but the time to reach maximum net growth rate after clipping does not change during the growing season (Brougham 1957, Morley 1968, Gillen and McGew 1987). Several studies have focused on season-long growth of ungrazed tallgrass prairie (Dwyer and Hutcheson 1965, Sims and Singh 1978, Gilbert et al. 1979), but there are little experimental data on the parameters which influence short-term growth rates of tallgrasses following defoliation. This study estimates the rates of live herbage accumulation on tallgrass prairie based upon the amount of live residual herbage remaining after grazing and season of defoliation.

The authors thank James Kulbeth and Mike Hayes for assistance in data collection. Published with approval of the Director, Oklahoma Agricultural Experiment Station, as JA-6185.

Manuscript accepted 3 Sept. 1993.

\section{Study Area}

The study was conducted on the Research Range of the Oklahoma Agricultural Experimental Station, at Stillwater, Okla. $\left(36^{\circ} 07^{\prime} \mathrm{N} 97^{\circ} 04^{\prime} \mathrm{W}\right)$ and on the Headquarters Farm, Unit II, of the Samuel Roberts Noble Foundation, Inc., at Ardmore, Okla. $\left(34^{\circ} 10 \mathrm{~N} 97^{\circ} 08^{\prime} \mathrm{W}\right)$. Average annual precipitation at Stillwater is $831 \mathrm{~mm}$ with $565 \mathrm{~mm}$ falling during a 204-day growing season. Average minimum and maximum temperatures range from $-4.3^{\circ} \mathrm{C}$ in January to $34.0^{\circ} \mathrm{C}$ in August with an overall mean temperature of $15.5^{\circ} \mathrm{C}$ (Myers 1982 ). Average annual precipitation at Ardmore is $875 \mathrm{~mm}$ with $565 \mathrm{~mm}$ falling during a 214 day growing season. Average minimum and maximum temperatures range from $0^{\circ} \mathrm{C}$ in January to $35.5^{\circ} \mathrm{C}$ in July with an overall mean temperature of $18^{\circ}$ C (Moebius et al. 1979).

The soil at the Stillwater study site is a Renfrow silt loam which is a fine, mixed, thermic, Udertic Paleustoll with a 3 to $5 \%$ westfacing slope. A dense subsurface at 30 to $40 \mathrm{~cm}$ causes the soil to be very slowly permeable (Henley et al. 1987). The area is a Claypan Prairie range site in high seral stage. Vegetation composition by weight on the study site consists of 33\% little bluestem (Schizachyrium scoparium (Michx.) Nash), 23\% big bluestem (Andropogon gerardii Vitman), 22\% indiangrass (Sorghastrum nutans (L.) Nash), 9\% switchgrass ( Panicum virgatum L.), 10\% other perennial grasses, and $3 \%$ forbs. Annual forage production averages $3,400 \mathrm{~kg} \mathrm{ha}^{-1}$ (Henley et al. 1987).

The soil at the Ardmore study site is a Clarita silty clay which is a fine, montmorillonitic, thermic Udic Pellustert with a 3 to $5 \%$ south-facing slope. This soil is deep, moderately well drained, and very slowly permeable. The study area is classified as a Blackclay Prairie range site in high seral stage. Vegetation on the site consists of $35 \%$ little bluestem, $15 \%$ big bluestem, $12 \%$ indiangrass, $7 \%$ switchgrass, $27 \%$ other perennial grasses, and $4 \%$ forbs by weight. Annual forage production on the site in an average year is $4,500 \mathrm{~kg}$ $\mathrm{ha}^{-1}$ (Moebius et al. 1979).

\section{Methods}

\section{Design}

Grazing trials were initiated on 26 May (Trial 1), 7 July (Trial 2), and 18 August (Trial 3) in 1989 and 1990. Each trial contained eight $20 \times 30 \mathrm{~m}(0.06 \mathrm{ha})$ treatment paddocks. A different set of paddocks were used for each trial. Paddocks were grazed for 1 to 2 days with dry cows and yearling cattle. Two paddocks per trial had stocking densities of $7,600,15,200,22,700$, and $30,300 \mathrm{~kg}$ animal weight $\mathrm{ha}^{-1}$. This treatment created a range of residual herbage levels $\left(\mathrm{kg} \mathrm{ha}^{-1}\right)$ among paddocks. Paddocks to be used for Trials 2 and 3 were moderately grazed $(6 \mathrm{~cm})$ at the initiation of Trial 1 , and paddocks for Trial 3 were grazed moderately at the initiation of Trial 2 to present a grazed vegetation environment for all trials. 


\section{Sampling}

Total herbage was measured immediately after grazing to determine residual herbage level, as well as $2,4,6$, and 8 weeks after grazing to determine standing crop accumulation. Vegetation in $20,0.1-\mathrm{m}^{2}$ plots per treatment paddock was hand-clipped to ground level. Field weight of each sample was recorded at harvest and samples were oven dried to determine dry weight. Field and dry weights of 8 samples each of pure live and pure dead plant material were obtained for each sampling date at Stillwater in 1989 and 1990 and Ardmore in 1990. Live and dead components of total herbage standing crop were calculated based on the moisture content of total, live, and dead plant material (Cooper et al. 1957, Gillen and Tate 1993). Live standing crop accumulation will be referred to as live herbage accumulation (LHA). Because no pure live or dead material was collected at Ardmore in 1989, live herbage accumulation could not be calculated for that year. Species composition at both study areas was determined in late summer by the dry-weight-rank method using $50,0.1-\mathrm{m}^{2}$ plots (Gillen and Smith 1986). Cattle were weighed once each year to facilitate allocation of livestock among paddocks.

\section{Live Herbage Accumulation}

Separate analyses of variance were conducted on live herbage accumulation data pooled within location and year. A repeated measures model was used with trial and live residual herbage level (LRHL) as main treatments and number of days after grazing (Day) as the repeated measure. Polynomial regression equations describing live herbage accumulation for each year and location were generated using independent variables determined to be significant by the analysis of variance $(P<0.05)$. Trial was incorporated into the models as an indicator variable.

\section{Live Herbage Accumulation Rate}

Equations describing live herbage accumulation rate (LHAR) for each trial and location were found as the first derivative with respect to Day of the live herbage accumulation equations. Following this procedure, live residual herbage level can only affect live herbage accumulation rate if the quadratic form of live residual herbage level or an interaction involving live residual herbage level is significant in the live herbage accumulation equations. Where live residual herbage level was significant, live herbage accumulation rate was plotted at 4 levels which defined the observed range of live residual herbage level for that particular trial.

\section{Results and Discussion}

\section{Weather Conditions}

Total annual precipitation at Stillwater for 1989 and 1990 was 940 and $950 \mathrm{~mm}$, compared to a long-term average of $831 \mathrm{~mm}$. Growing season precipitation (April to September) from 1989 and 1990 was 680 and $520 \mathrm{~mm}$, while the long-term average is $565 \mathrm{~mm}$. Precipitation during all trials in 1989 was at least $70 \mathrm{~mm}$ above the long-term average, and average temperatures were consistently below normal (Table 1). Precipitation during Trials 1 and 2 of 1990 was 155 and $50 \mathrm{~mm}$ below average, respectively. Trial 3 of 1990 experienced slightly above-average precipitation. Temperatures exceeded the average for all trial periods in 1990. In summary, weather conditions at Stillwater during the 1989 growing season were more favorable for forage production than in 1990.

Total annual precipitation at Ardmore in 1990 was $1,529 \mathrm{~mm}$. The long-term average is $874 \mathrm{~mm}$. Growing season precipitation in 1990 was $865 \mathrm{~mm}$, compared to a long-term average of $575 \mathrm{~mm}$. Precipitation was $56 \mathrm{~mm}$ above average during Trial 1 but was near average and slightly above average during Trials 2 and 3, respectively (Table 1). Although growing season precipitation was high it was not well distributed temporarlly with April and May receiving
Table 1. Weather data for each trial, $\mathbf{P}=$ precipitation, $T=$ temperature, Max = average maximum daily temperature, Min $=$ average minimum daily temperature, Daily = average daily temperature.

\begin{tabular}{|c|c|c|c|c|c|c|}
\hline \multirow[b]{2}{*}{ Location } & \multirow[b]{2}{*}{ Trial } & \multirow[b]{2}{*}{ Year } & \multirow[b]{2}{*}{$\mathbf{P}$} & \multirow[b]{2}{*}{ Max } & \multicolumn{2}{|c|}{$\mathrm{T}$} \\
\hline & & & & & Min & Daily \\
\hline & & & $\mathrm{mm}$ & $\ldots$ & $-{ }^{\circ} \mathrm{C}$ & $\cdots$ \\
\hline \multirow[t]{9}{*}{ Stillwater } & 1 & 89 & 376 & 28 & 17 & 23 \\
\hline & & 90 & 148 & 30 & 18 & 24 \\
\hline & & Avg & 303 & 30 & 17 & 23 \\
\hline & 2 & $89^{\circ}$ & 280 & 31 & 19 & 25 \\
\hline & & 90 & 155 & 33 & 21 & 27 \\
\hline & & Avg & 205 & 33 & 21 & 27 \\
\hline & 3 & 89 & 276 & 28 & 15 & 23 \\
\hline & & 90 & 224 & 33 & 19 & 26 \\
\hline & & Avg & 185 & 31 & 18 & 24 \\
\hline \multirow[t]{6}{*}{ Ardmore } & 1 & 90 & 257 & 32 & 21 & 27 \\
\hline & & Avg & 201 & 33 & 21 & 27 \\
\hline & 2 & $90^{\circ}$ & 151 & 33 & 22 & 28 \\
\hline & & Avg & 148 & 35 & 22 & 29 \\
\hline & 3 & 90 & 224 & 32 & 20 & 26 \\
\hline & & Avg & 193 & 32 & 19 & 26 \\
\hline
\end{tabular}

twice their normal rainfall and the remaining 3 months of the growing season receiving average amounts of precipitation. Temperatures for all trials at Ardmore were at or near average. At Ardmore, 1990 was an excellent year for forage production due to high soil moisture early in the season and average precipitation throughout the remainder of the growing season.

\section{Live Herbage Accumulation}

Trial, live residual herbage level, Day, and Trial*Day were significant $(P<0.05)$ sources of variation in the analysis of variance for all location by year combinations (Table 2). The live residual herbage level by Day interaction was significant for both years at Stillwater, and the Trial by live residual herbage level by Day interaction was significant at Stillwater in 1990. It should be noted that a single regression model was developed for each location by year combination. For clarity in later analysis, a separate equation was written for each trial by algebraic simplification of the full model (Table 3). Regression models accounted for 74 to $81 \%$ of the observed variation in live herbage accumulation (Table 3). A plot of the best fit, Stillwater 1990 Trial 2, and the worst fit, Stillwater 1989 Trial 3, is presented to give some indication of how the regression equations fit the live herbage accumulation data (Fig. $1)$.

Table 2. Analysis of variance for live herbage accumulation data at Stillwater 1989, 1990, and Ardmore 1990.

\begin{tabular}{|c|c|c|c|c|}
\hline \multirow[b]{3}{*}{ Source } & \multirow[b]{3}{*}{ df } & \multicolumn{3}{|c|}{$\mathbf{P}$} \\
\hline & & \multicolumn{2}{|c|}{ Stillwater } & \multirow{2}{*}{$\begin{array}{c}\text { Ardmore } \\
1990\end{array}$} \\
\hline & & 1989 & 1990 & \\
\hline Trial & 2 & 0.001 & 0.044 & 0.001 \\
\hline LRHL & $\overline{1}$ & 0.001 & 0.001 & 0.001 \\
\hline Trial*LRHL & 2 & 0.133 & 0.188 & 0.942 \\
\hline LRHL $^{2}$ & 1 & 0.115 & 0.187 & 0.364 \\
\hline Trial*LRHL ${ }^{2}$ & 2 & 0.890 & 0.580 & 0.692 \\
\hline Day & 4 & 0.001 & 0.001 & 0.001 \\
\hline Trial*Day & 8 & 0.001 & 0.001 & 0.001 \\
\hline LRHL*Day & 4 & 0.012 & 0.001 & 0.076 \\
\hline Trial*LRHL*Day & 8 & 0.540 & 0.001 & 0.864 \\
\hline LRHL $^{2 *}$ Day & 4 & 0.461 & 0.432 & 0.235 \\
\hline Trial*LRHL $2 *$ Day & 8 & 0.909 & 0.427 & 0.471 \\
\hline C.V. & & 11.936 & 13.726 & 16.558 \\
\hline MSE & & 300.078 & 161.489 & 215.726 \\
\hline
\end{tabular}


Table 3. Statistics and coefficients of polynomial regression equations for live herbage accumulation. All parameters significant at $P<0.05$.

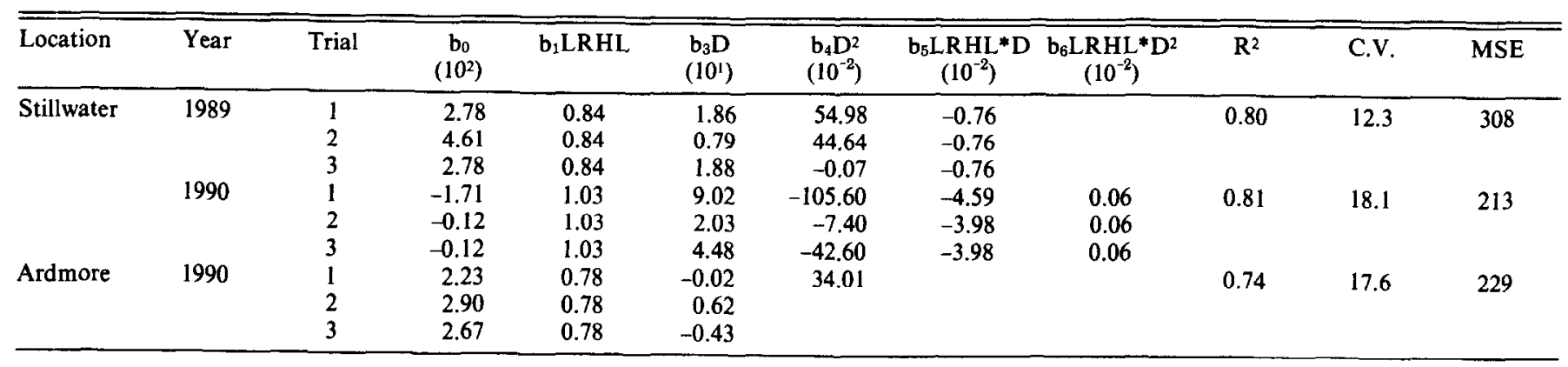

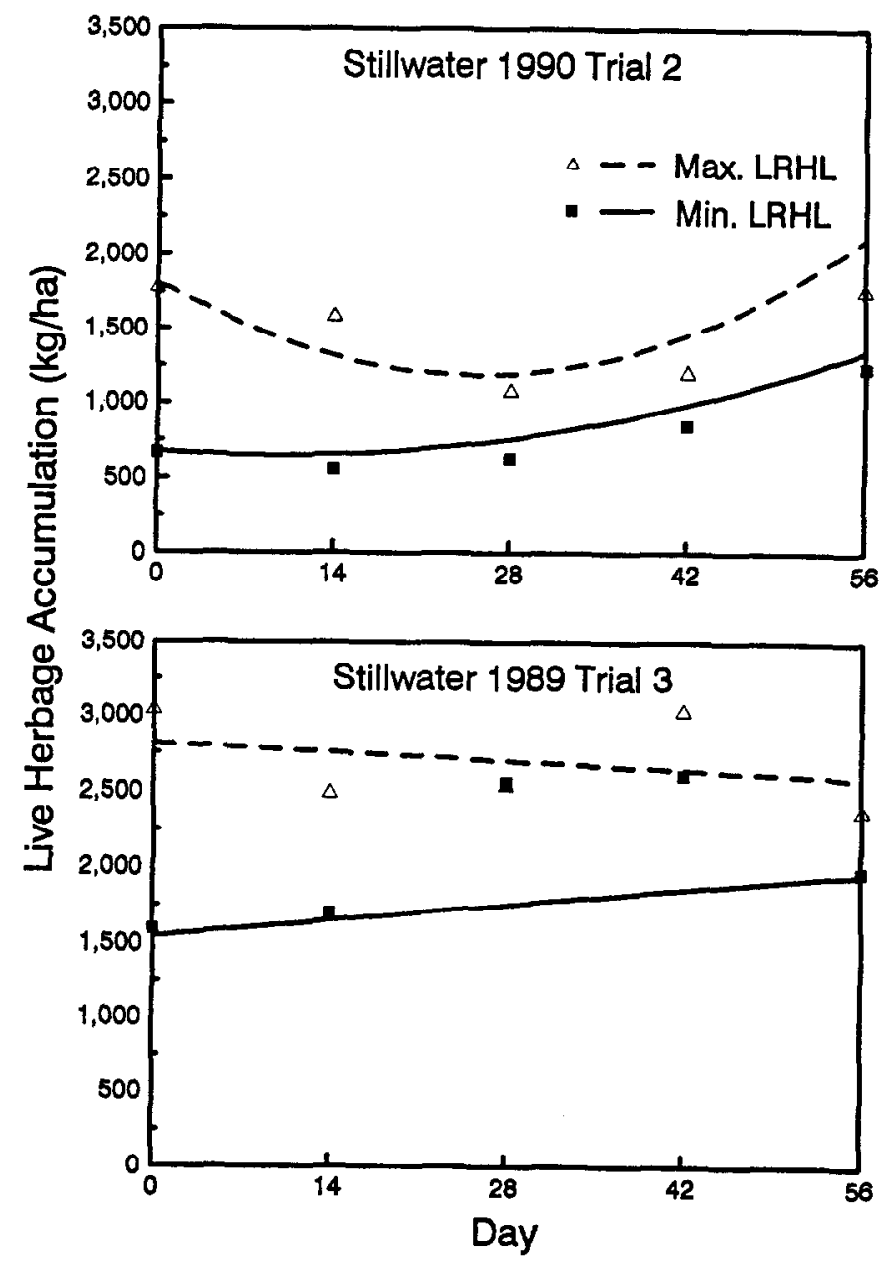

Fig. 1. Predicted versus observed live herbage accumulation for Stillwater 1990 Trial 2 and Stillwater 1989 Trial 3.

\section{Live Herbage Accumulation Rate}

\section{Season}

Maximum live herbage accumulation rate and the difference in live herbage accumulation rate among trials decreased as season progressed in both years and at both locations. Live herbage accumulation rate for Trials 1,2 , and 3 ranged from -30 to $80,-50$ to 60 , and -5 to $30 \mathrm{~kg} \mathrm{ha}^{-1} \mathrm{~d}^{-1}$, respectively, across years and locations (Fig. 2, 3, and 4). Time required to reach maximum live herbage accumulation rate varied widely, and did not seem to depend on season. Maximum live herbage accumulation rate was attained on the last day of Trials 1 and 2 of 1989, Trial 2 of 1990 at Stillwater, and Trial 1 at Ardmore. Maximum live herbage accumulation rate for all treatments in Trial 1 and some in Trial 3 at
Stillwater in 1990 was attained on the first day of the trial (Fig. 3). Live herbage accumulation rate was not affected by Day in Trial 2 or 3 at Ardmore. These results support previous findings that maximum net growth rate is dependent upon season but time to maximum growth rate is not dependent upon season (Brougham 1957, Anslow and Green 1967, Morley 1967, Williams 1980, Gillen and McNew 1987, Brummer et al. 1988). Voisin (1959) believed that maximum net growth rate remained constant as season progressed, but that time to maximum net growth rate increased with season.

Negative live herbage accumulation rate at the initiation of Trial 2 of both years at Stillwater indicates a lag or recovery phase immediately after grazing. High live residual herbage levels and above-average precipitation $(+70 \mathrm{~mm})$ in 1989 , and low live residual herbage levels and below-average precipitation $(-50 \mathrm{~mm})$ in 1990 rule out precipitation as a casual factor. Anslow and Green (1967) found a natural decline in growth rate at the same period of the growing season when Trial 2 occurred.

In Trial 3 at Ardmore day after grazing was not a significant parameter in live herbage accumulation equations, and it had minimal effect during Trial 3 at Stillwater 1989. Tallgrass vegetation has limited regrowth potential after August 1 (Gillen and McNew 1987).

\section{Live Residual Herbage Level}

Live herbage accumulation rate was significantly related to live residual herbage level for all trials at Stillwater, and was not related to live residual herbage level in any trial at Ardmore (Table 4). The

Table 4. Coefficients of live herbage accumulation rate equations derived from regression equations for live herbage accumulation.

\begin{tabular}{lcccccc}
\hline \hline Location & Year & Trial & $\begin{array}{c}\mathrm{b}_{0} \\
\left(10^{1}\right)\end{array}$ & $\begin{array}{c}\mathrm{b}_{1} \mathrm{LRHL} \\
\left(10^{-2}\right)\end{array}$ & $\begin{array}{c}\mathrm{b}_{2} \mathrm{D} \\
\left(10^{-1}\right)\end{array}$ & $\begin{array}{c}\mathrm{b}_{3} \mathrm{LRHL}^{*} \mathrm{D} \\
\left(10^{-2}\right)\end{array}$ \\
\hline Stillwater & 1989 & 1 & 1.86 & -0.76 & 10.99 & \\
& & 2 & 0.79 & -0.76 & 8.90 & \\
& & 3 & 1.88 & -0.76 & -0.01 & \\
& \multirow{2}{*}{1990} & 1 & 9.02 & -4.59 & -21.12 & 0.12 \\
& & 2 & 2.03 & -3.98 & -1.48 & 0.12 \\
Ardmore & 1990 & 3 & 4.48 & -3.98 & -8.52 & 0.12 \\
& & 1 & -0.02 & & 6.80 & \\
& & 2 & 0.62 & & & \\
\hline
\end{tabular}

explanation for the differences between Stillwater and Ardmore is not readily clear. There is no evidence to support climate as an explanation (Table 1).

There are differences in the effect live residual herbage level had on live herbage accumulation rate at Stillwater in 1989 and 1990. During 1989, live residual herbage level caused the initial live herbage accumulation rate to vary with live residual herbage level, but the slope or rate of change was the same. For all trials at 


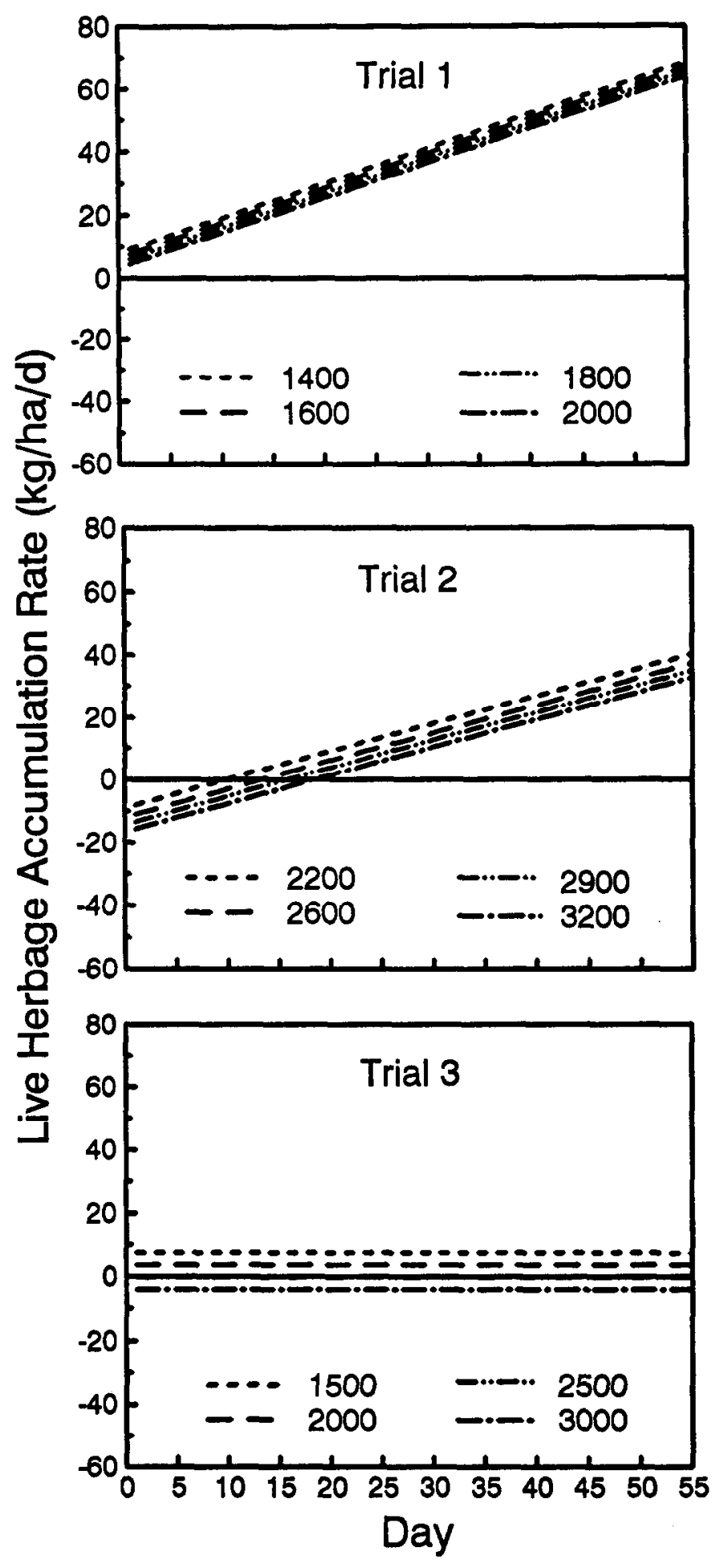

Fig. 2. Live herbage accumulation rate for Stillwater 1989. Plots represent the first derivative with respect to Day of regression equations predicting live herbage accumulation at Stillwater in 1989. Multiple lines represent the range of observed live residual herbage level for the trial.

Stillwater in 1989 the most intensely grazed paddocks, i.e., lowest live residual herbage level, had the highest growth rates (Fig. 2). Due to the presence of the live residual herbage level by Day² interaction in the live herbage accumulation equation for Stillwater 1990, the live residual herbage level by Day interaction became a parameter in the live herbage accumulation rate equation. Thus live residual herbage level influenced not only the initial
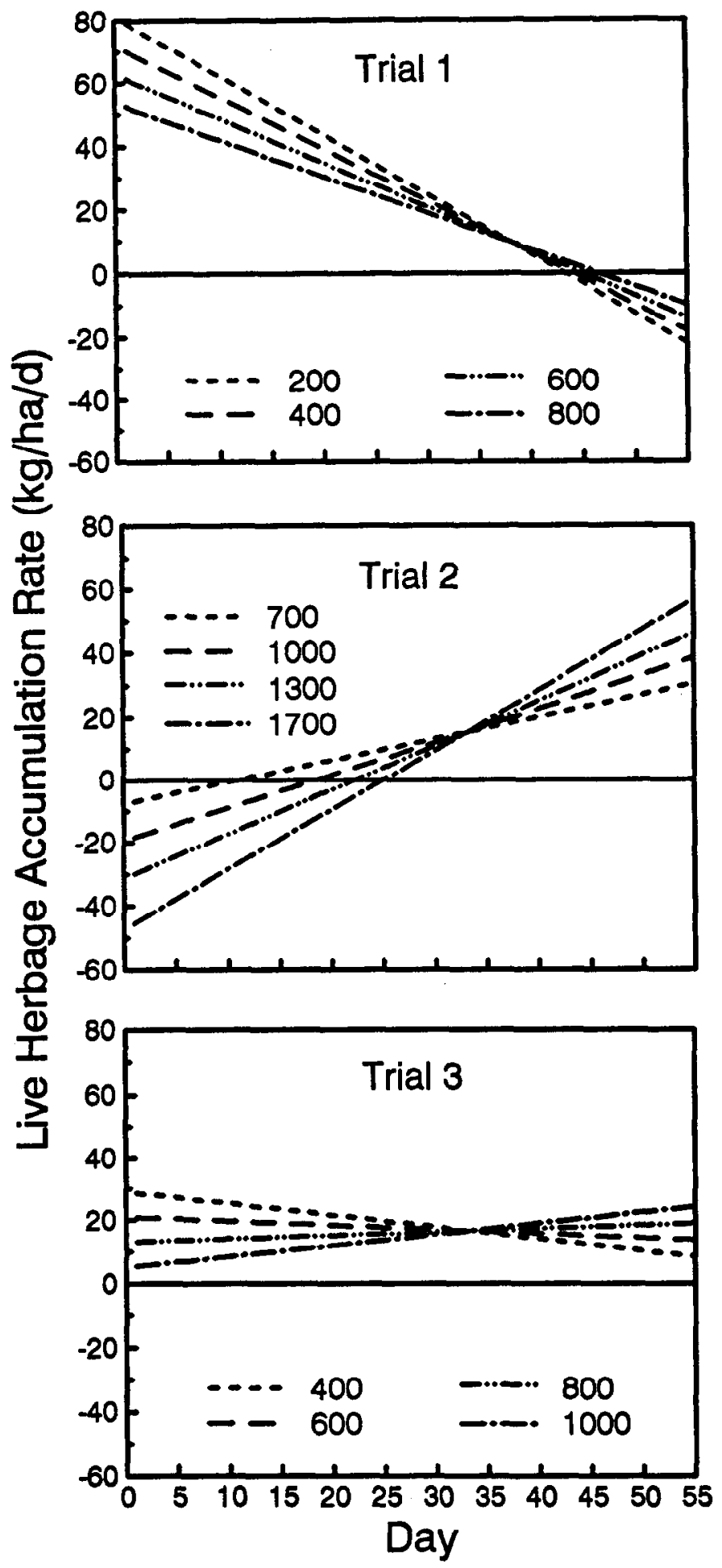

Fig. 3. Live herbage accumulation rate for Stillwater 1990. Plots represent the first derivative with respect to Day of regression equations predicting live herbage accumulation at Stillwater in 1990. Multiple lines represent the range of observed live residual herbage level for the trial.

live herbage accumulation rate, but the rate of change. In all trials at Stillwater 1990 the most intensely grazed paddocks had the highest initial live herbage accumulation rate, but had the lowest final live herbage accumulation rate (Fig. 3).

One explanation for the different effect of live residual herbage level on live herbage accumulation rate at Stillwater in 1989 and 1990 might be rainfall. Precipitation was well above average for all 

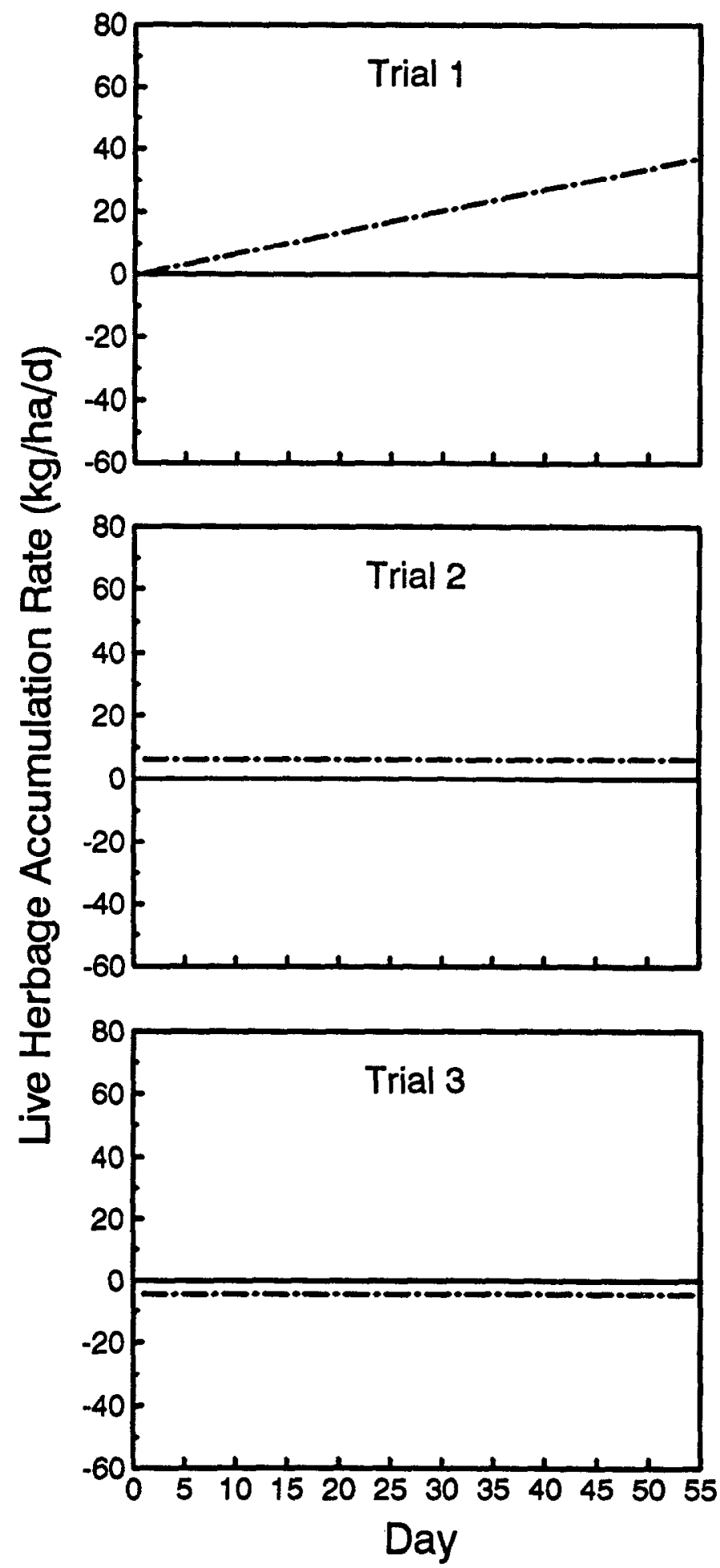

Fig. 4. Live herbage accumulation rate for Ardmore 1990. Plots represent the first derivative with respect to Day of regression equations predicting live herbage accumulation at Ardmore in 1990. Single lines indicate live herbage accumulation rate was not affected by live residual herbage level.

of 1989 , but was well below average for the majority of 1990 . Moisture stress may have compounded the effects of defoliation to produce the results observed in 1990.

\section{Conclusions}

Live herbage accumulation rate of tallgrass prairie was affected by timing of defoliation within the growing season. Maximum live herbage accumulation rate and the amount of change in live herbage accumulation rate throughout a trial decreased as season progressed, but the amount of time required to attain maximum live herbage accumulation rate was variable and independent of season. These findings substantiate the conclusions of several studies (Brougham 1957, Anslow and Green 1967, Morley 1967, Williams 1980, Gillen and McNew 1987, Brummer et al. 1988). Regrowth potential of tallgrass prairie is limited in August.

Live residual herbage level was a significant parameter in 6 of 9 equations describing live herbage accumulation rate. Climatic differences do not explain why live herbage accumulation rate was not related to live residual herbage level at Ardmore, but was at all trials in Stillwater. However, low precipitation at Stillwater in 1990 compared to 1989 might account for differences in the level of effect live residual herbage level had on live herbage accumulation rate.

Although live residual herbage level influences live herbage accumulation rate, the rate and pattern of regrowth of tallgrass prairie following defoliation is too complex to be explained by defoliation intensity alone. Future research must identify and quantify additional factors such as precipitation, soil moisture, and morphological stage at defoliation which interact with defoliation intensity to influence live herbage accumulation rates.

\section{Literature Cited}

Anslow, R.C., and J.O. Green. 1967. The seasonal growth of grasses. J. Agr. Sci., Cambridge. 68:109-122.

Booysen, P. De V., and N.M. Tainton. 1978. Grassland management: principles and practice in South Africa, p. 551-554. In: D.N. Hyder (ed.), Proc. 1st Int. Rangeland Congr., Soc. Range Manage., Denver, Colo.

Brougham, R.W. 1957. Effect of defoliation on regrowth of pasture. Aust. J. Agr. Res. 7:377-387.

Brummer, J.E., R.L. Gillen, and F.T. McCollum. 1988. Herbage dynamics of tallgrass prairie under short duration grazing. J. Range Manage. 41:264-266.

Cooper, C.S., D.N. Hyder, R.G. Petersen, and F.A. Sneva. 1957. The constituent differential method of estimating species composition in mixed hay. Agron. J. 49:190-193.

Dwyer, D.D., and H.L. Hutcheson. 1965. Growth rate of four range grasses in North Central Oklahoma. Oklahoma Exp. Sta. Bull. B-683.

Gilbert, W.L., L.J. Perry, Jr., and J. Stubbendieck. 1979. Dry matter accumulation of four warm-season grasses in the Nebraska sandhills. J. Range Manage. 32:52-54.

Gillen, R.L., and R.W. McNew. 1987. Seasonal growth rates of tallgrass prairie after clipping. J. Range Manage. 40:342-345.

Gillen, R.L., and E.L. Smith. 1986. Evaluation of the dry-weight-rank method for determining species composition in tallgrass prairie. J. Range Manage. 39:283-285.

Gillen, R.L., and K.W. Tate. 1993. An evaluation of the constituent differential method for determining live and dead herbage fractions. J. Range Manage. 46:142-147.

Henley, J.R., R.D. Gelnar, and R.E. Mayhugh. 1987. Soil survey of Payne County, Oklahoma. USDA, SCS.

Howell, L.N. 1978. Development of multi-camp grazing systems in the Southern Orange Free State, Rep. S. Africa. J. Range Manage. 31:459-465.

Moebius, G.E., and A.J. Maxwell. 1979. Soil survey of Carter County, Oklahoma. USDA, SCS.

Morley, F.H.W. 1968. Pasture growth curves and grazing management. Australian J. Exp. Agr. Anim. Husb. 8:40-45.

Myers, H. 1982. Climatological data of Stillwater, Oklahoma 1893-1980. Oklahoma Agr. Exp. Sta. Res. Rep. P-821.

Savory, A. 1978. A holistic approach to ranch management using short duration grazing, p. 555-557. In: D.N. Hyder (ed.), Proc. 1st Int. Rangeland Congr., Soc. Range Manage., Denver, Colo.

Sims, P.L., and J.S. Singh. 1978. The stucture and function of ten western North American grasslands. IV. Comparative transfers and energy flow within the ecosystem. J. Ecol. 66:983-1009.

Voisin, A. 1959. Grass productivity. Philosophical Library, Inc., N.Y.

Williams, T.E. 1980. Herbage production: grasses and leguminous forage crops, p. 6-69. In: W. Holmes (ed.), Grass: Its production and utilization. Blackwell Sci. Pub., London. 